\title{
THE PROBLEMS OF INFORMAL CAREGIVERS ON LONG-TERM CAREGIVING OF THE ELDERLIES
}

\author{
Suridah Ali ${ }^{1}$, Rahimah Abdul Aziz ${ }^{1}$ and Mimi Hanida Abdul Mutalib ${ }^{1}$ \\ ${ }^{1}$ Center for Research in Development, Social \& Environment, Faculty of Social Sciences \& Humanities, National \\ University of Malaysia, 43600 Bangi Selangor.
}

Corresponding author: Suridah Ali

Email: suridah22@gmail.com

\begin{abstract}
Malaysia is expected to become the elder country by the year of 2035 and the elderly caregiving is the main issue in old population. Although the elderlies are expected to live for a longer period, half of them are in unhealthy condition, sick and suffering from disease. Thus, they need to be taken care for a longer period formally or informally. However, most of the family members have chosen to take care the elderlies informally. Therefore, the purpose of this article is to identify the problems that are faced by the caregivers on long-term caregiving of the elderlies. Informal caregivers need to encounter financial problem, affected health, difficulty in determining the caregiving rotation and lack of knowledge or information pertaining to elderly caregiving. Hence, the roles of caregiving in long-term period could burden and affect the informal caregivers' well-being.
\end{abstract}

Keywords: Informal Caregivers, Elderlies, Informal Caregiving, Long-term Care, Well-being

\section{INTRODUCTION}

The industrial and development processes have caused the changes in community demographics ${ }^{1}$. The changes that happen have increased elderly total population because the life expentency of world communities increase and the death rate decreases. The increase in the number of the elderly has resulted Malaysia to become an elder country by the year of 2035². In 2019, the population aged 60 years and above is estimated $10.3 \%$ of the total population (32.6 million) ${ }^{3}$. In elder communities, the elderly caregiving becomes the main issue. The increase in the numbers of elderlies who are sick have also increased the demand for caregiving. The caregiving towards the sick ederlies needs to be done formally or informally for a long-term period. World Health Organization (WHO) defines long-term care as the a caregiving activity done by informal caregivers (family, friends dan neighbors) or professional caregivers (health and social service) to ensure the ederlies who are unable to take care of themselves to be taken care in a better way ${ }^{4}$. Formal caregiving is usually done in nursing home and day care center owns by government, non-government organization or private. In a formal caregiving, the elderlies are taken care by professional and trained caregivers. The nursing homes and care centers are equipped with the facilities according to the elderlies needs. However, the facilites that are prepared in the elderly care centers are not enough to accomodate the increasing residents ${ }^{5}$.

As for an informal caregiving, the caregivers choose to take care their sick family members at home. Even as the times progress, the communities in Malaysia still have the strong values of responsibility in taking care the elderlies. Moreover, the elderlies still depend on the their family members when they are sick. In addition, the families are likely wanted to prevent in placing the sick and unabled ederlies in caregiving centers to avoid the stigma of society ${ }^{6}$. Usually, the close family members such as their children, spouse and relatives are the informal caregivers ${ }^{7}$. However, the family members are actually not capable to equip the quality caregiving to the elderlies. This is because, the long-term care of the elderlies could contribute to various problems to caregivers. Therefore, this article will dismantle the problems that are faced by informal caregivers in long-term period.

\section{METHODS}

The research on the elderlies' life expentency was conducted in Mukim Kota Putera, Besut Terengganu. The research population was the informal caregivers who caregiving the sick elderlies for a longer period which was more than three months. This research involved 12 informal caregivers as the sample of the study. The informal caregivers consisted of elderlies' own family members which were spouse, children and daughter-in-law. The selection of smaller sample size was relevant to the in-depth case study ${ }^{8}$.

\section{Data Collection and Analysis}

Sampling method of snowball was used in the selection of research informants. The researchers have obtained information from Penghulu Mukim and Ketua Kampung to identify the informants. The selections of research infromants were based on three main criteria which were; first, informants must be the primary informal 
caregivers of the sick elderly, second, informants must take care of the elderly for full time for a longer period and must live together with the elderly. The researchers employed the in-depth interview method and non-partcipating observation to obtain the research data. Each interview session took about two hours and was conducted twice per informant. The interview session conducted in informant's house without being influenced by other individuals. After all, the informant needed to take care and monitor the sick elderly in the house at the same time. In addition, the researchers also needed to retrieve the non-participating observation data. The researchers employed thematic analysis method to analyse the research data. In the analysis process, the researchers transcribe the data first. Every collected data was rewrote, re-read and coded. After that, the potential themes emerged. The ongoing analysis was done to refine and specify each theme. Finally, each theme emerged that were suitable with the research issue.

\section{RESULTS}

Informants' socio demographic profiles

This research involved eleven (11) female informants and one male informant who taking care of sick and disabled elderlies. All informants were aged between 21 to 70 years old, Muslims and Malays. For the marital status, eight informants were married, two informants were single, one informant was a widow (husband's death) and one informant was a divorcee. The highest education status of the informants was in Diploma level while the lowest education status was in standard 6. In term of income, there were among the informants who did not have any incomes because they were not working, some received the financial aid from Department of Social Welfare Malaysia (JKM) and some were selfemployed. For the informants who had working children like Kak Nah, Cik Der, Mok Cik Sah and Kak Yah, they received the grant money from their children. Moreover, there was a teacher retiree informant who received pension money every month. Besides taking care of the sick elderly, they also had the diseases such as high blood pressure, diabetes, heart disease, high cholesterol and knee pain. Informants' socio demographic profiles could be seen in Table 1.

Table 1a: Socio-demographic characteristics of the caregivers (informants)

\begin{tabular}{|c|c|c|c|c|c|c|c|}
\hline $\begin{array}{l}\text { Informant's } \\
\text { Names } \\
\text { (nickname) }\end{array}$ & $\begin{array}{l}\text { Age } \\
\text { (Years) }\end{array}$ & $\begin{array}{l}\text { Marital } \\
\text { Status }\end{array}$ & $\begin{array}{l}\text { Number } \\
\text { of } \\
\text { Children } \\
\text { (persons) }\end{array}$ & Occupation & $\begin{array}{l}\text { Incomes } \\
\text { (RM) }\end{array}$ & $\begin{array}{l}\text { Type of } \\
\text { Disease }\end{array}$ & $\begin{array}{l}\text { Level of } \\
\text { Education }\end{array}$ \\
\hline Mok Su & 70 & Married & 2 & - & - & Hypertension & Standard 6 \\
\hline Kak Nah & 59 & Married & 12 & - & 400.00 & Hypertension & Standard 6 \\
\hline Cik Der & 58 & Married & 6 & - & 300.00 & Hypertension & Standard 6 \\
\hline Ramlah & 61 & Married & 8 & - & - & $\begin{array}{l}\text { High } \\
\text { cholesterol }\end{array}$ & Standard 6 \\
\hline Azi & 21 & Single & - & - & - & - & STPM \\
\hline Azmi & 24 & Single & - & - & $\begin{array}{l}200.00 \\
\text { (JKM } \\
\text { assistance) }\end{array}$ & - & Form 2 \\
\hline Mok Cik Sah & 59 & Married & 9 & - & 100.00 & $\begin{array}{l}\text { Hypertension, } \\
\text { knee pain }\end{array}$ & Form 3 \\
\hline Hani & 31 & Married & $\begin{array}{l}1 \\
\text { (Special } \\
\text { Child) }\end{array}$ & - & $\begin{array}{l}\text { *300.00 } \\
\text { (JKM } \\
\text { assistance) } \\
* 900.00 \\
\text { (Husband's } \\
\text { salary) }\end{array}$ & - & STPM \\
\hline
\end{tabular}


Table 1b: Socio-demographic characteristics of the caregivers (informants)

\begin{tabular}{|c|c|c|c|c|c|c|c|}
\hline Mok Teh & 57 & Widow & $\begin{array}{l}12 \\
* 4 \\
\text { children } \\
\text { who } \\
\text { attend } \\
\text { the } \\
\text { school }\end{array}$ & $\begin{array}{l}\text { Works in } \\
\text { eatery }\end{array}$ & 400.00 & $\begin{array}{l}\text { Diabetes, } \\
\text { knee pain }\end{array}$ & Form 3 \\
\hline Cikgu & 62 & Married & $\begin{array}{l}7 \\
\text { *an OKU } \\
\text { daughter }\end{array}$ & $\begin{array}{l}\text { Teacher } \\
\text { retiree }\end{array}$ & $\begin{array}{l}3000.00 \\
\text { (pension } \\
\text { money) }\end{array}$ & - & Diploma \\
\hline Cik Mah & 46 & Divorcee & - & Nanny & 350.00 & - & Form 3 \\
\hline Kak Yah & 58 & Married & 5 & - & 200.00 & $\begin{array}{l}\text { Heart disease, } \\
\text { Hypertension } \\
\text { \& high } \\
\text { cholestrol }\end{array}$ & $\begin{array}{l}\text { Standard } \\
6\end{array}$ \\
\hline
\end{tabular}

*STPM= Sijil Tinggi Pelajaran Malaysia (Malaysia Higher School Certificate)

Type of relationship, duration of caregiving and health status of caregiver

In term of caregiving, Table 2 shows the type of relationship between caregiver and elderly, duration of caregiving and elderly health status. Pertaining to type of relationship between the caregiver and elderly, it showed that the caregiver was from the close family member with the elderly. The caregivers were from the spouse, wife and children. This was parallel with the result of the research that indicated the sick elderlies depended on their close family members to take care of them when they were sick. Table 2 highlights the caregivers who take care the sick elderlies for a long period which is between more than a year until 15 years. Besides, the types of diseases and health status are also shown in Table 2. Most of the elderlies suffered from stroke disease, high blood pressure, diabetes, chronic kidney disease and other movement problems, sick and sight problems.

Table 2: Type of relationship, caregiving duration and elderlies' health status

\begin{tabular}{|c|c|c|c|c|c|}
\hline $\begin{array}{l}\text { Name of } \\
\text { Elderlies } \\
\text { (nickname) }\end{array}$ & Caregiver & Relationship & Type of Disease & $\begin{array}{l}\text { Caregiving } \\
\text { Duration } \\
\text { (year) }\end{array}$ & Health Status \\
\hline Pak Hasan & Mok Su & Wife & $\begin{array}{ll}\text { - } & \text { Kidney } \\
& \text { Disease } \\
\text { - } & \text { Gout } \\
\text { - } & \text { Lung }\end{array}$ & $1>$ & Disabled \\
\hline Pak Su & Kak Nah & Wife & $\begin{array}{l}\text { - Stroke } \\
\text { - Diabetes } \\
\text { - Hypertension }\end{array}$ & $1>$ & Sick \\
\hline Pak Lah & Cik Der & Wife & $\begin{array}{l}\text { - Stroke } \\
\text { - Hypertension }\end{array}$ & 15 & $\begin{array}{l}\text { Movement and } \\
\text { Speech Problem }\end{array}$ \\
\hline Pak Mat & Ramlah & Wife & $\begin{array}{l}\text { - Kidney } \\
\text { Disease }\end{array}$ & 1 & Disabled \\
\hline Ismail & Azi & Child & - Stroke & 10 & $\begin{array}{ll}\text { Sick, } & \text { Speech } \\
\text { Problem } & \end{array}$ \\
\hline Zainab & Azmi & Child & - Stroke & 15 & $\begin{array}{l}\text { Movement Problem, } \\
\text { Paralyzed on the } \\
\text { Left Side of the } \\
\text { Body }\end{array}$ \\
\hline Ayah Ziz & Mak Cik Sah & Wife & - Stroke & 1> & $\begin{array}{l}\text { Disabled, Movement } \\
\text { Problem }\end{array}$ \\
\hline Mak Leha & Hani & Daughter-in-law & $\begin{array}{l}\text { Kidney } \\
\text { Disease } \\
\text { - Diabetes }\end{array}$ & 4 & $\begin{array}{l}\text { Disable, Amputated } \\
\text { Left Leg }\end{array}$ \\
\hline Pak Harun & Mok Teh & Child & $\begin{array}{l}\text { - Old Age } \\
\text { - Blurry Sight }\end{array}$ & 1 & $\begin{array}{l}\text { Disabled, } \\
\text { Problem }\end{array}$ \\
\hline Pak Rashid & Teacher & Wife & $\begin{array}{l}\text { - Diabetes } \\
\text { - Heart Disease }\end{array}$ & 2 & $\begin{array}{l}\text { Disabled, } \\
\text { Problem }\end{array}$ \\
\hline Pak Ahmad & Cik Mah & Child & $\begin{array}{l}\text { - Stroke } \\
\text { - Nerve }\end{array}$ & 2 & Movement Problem \\
\hline Pak Man & Kak Yah & Wife & $\begin{array}{l}\text { - Heart Disease } \\
\text { - } \text { Prostatitis }\end{array}$ & 1 & Movement Problem \\
\hline
\end{tabular}




\section{Caregiving problems encountered by informal caregivers}

This research found out that taking care of the elderlies for a longer period could bring various problems to caregivers. The problems encountered by informal caregivers were financial problem, health problem, schedule of caregiving rotation, and lack of information pertaining to elderlies' caregiving and their diseases.

\section{i) Financial Problem}

Taking care of the sick elderlies needed the high living expenditures. Instead of self-expenses, the caregivers also needed to spend half of their incomes to treat the elderlies' health, transportation to the hospital and daily care matter. Financial problems could be the burden to the caregivers. This was because, most of the informants were from low income groups. For Mak Cik Sah, she encountered financial problem after her husband who was a sole breadwinner, diagnosed with stroke disease a year ago. She informed,

“...priorly, the income was RM2000.00 when Ayah Ziz was working...currently, there is no income, it all depends on our children who provide us RM 100 (per month)....".

The financial problem encountered by the informants has pressured them. Although they took care of the elderlies as the part of responsibility in the beginning, the financial problem that arose has burdened them. Informant Azmi, who is a Human Deficient Effort (HDE), forced to quit his job to take care of his mother who was diagnosed with stroke disease. He only received the aid from Department of Social Welfare Malaysia (JKM) to support himself, the sick mother and the unemployed brother. He informed,

"...currently, I am unemployed.. no income..but I receive the financial aid.. my mother has received RM300.00, I have received $R M 200.00$.. we receive this financial aid every month..we do not have any savings, the financial aid is used for daily expenses..."

\section{ii) Health Problem}

According to the research conducted in Besut, the researcher found out that most of the informants who were the caregivers, diagnosed with hypertension, diabetes, heart disease, high cholestrol and knee pain. They informed that it was hard to execute the caregiving role very well due to their limited abilities. Therefore, they felt that the caregiving role was a burden for them. As was being told by Mak Cik Sah, "...currently, I encounter the pain in my ass...I have swallowed the medicine...my legs feel numb...how is gout disease?..l feel the pain in here..is it gout or what..swollen at the leg joint...l was involved in the accident priorly..not capable to buy expensive medicines..."

Kak Nah also told,

“...I have hypertension...I will feel dizzy if I do not get enough sleep..He sleeps during the day, then he cannot sleep at night..."

\section{iii) Caregiving Rotation}

The sick elderlies usually preferred to be taken care by their daughter than their son. The son should be responsible to take care of their sick parents but the physical caregiving usually becomes the daughter's role ${ }^{9}$. The research conducted by Khadijah Alavi et al (2010) found out that parents were comfortable to live with their daughter dan they had strong bond than the son ${ }^{10}$. The roles of women in elderly caregiving were suitable with their caring, loving and concerned characters and personalities ${ }^{11}$. As being told by informant Mok Teh,

“...Mok Teh's father does not really like to live with his son.. if he goes, it is just for a while...then, he will come back here...yes...his daughter-in-law, how well does she care...my father only lives here, he goes to my younger brother for a short period... the longest is for a week...Mok Teh does not have any problems if he wants to stay here...but Mok Teh needs to go back and forth during trading..."

Informant Hani, besides taking of care ofher mother-in-law, she also took care of her three years old special child. She informed,

“...I am a daughter-in-law, lives only three of us..my husband works in Kuala Lipis, rarely going back...he is lorry driver...there are no other children living here, there is a child who lives nearby...the youngest lives in Sarawak, will be back during holiday... i live here, $i$ don't have my own house...mother is sick...thus, $i$ take care of her...i pity her because she cannot walk, only indent... 
iv) Lack of Information or Knowledge Pertaining to Elderly Caregiving and Disease

The role of caregivers needed them to always be alert and provided full attention towards the sick elderlies. The elderlies' condition needed to be monitored every time to ensure the caregivers realized about the actions that should be taken. Therefore, the caregivers need to obtain information and knowledge pertaining elderlies' cares and their health condition. Caregivers need to have exact information to ease the hospital staff in treating the elderlies better ${ }^{12}$. Every change that happens every day must be recorded or remembered. However, most informants in this research did not have information or knowledge either in term of the caregiving role or the elderlies' diseases. Kak Nah informed the researcher that she did not have the exact information or knowledge on her husband's disease,

"...currently, he was unable to poo... he was a hard type and will be flutterly sick, once in a month...when he first encountered, it was like death... called his children to come back home... when we brought him to hospital, we got to know that actually he wanted to poo... he was admitted in hospital for two days..."

The other caregiver, Kak Yah also told,

"...the poo was smelly...the doctor asked, how long did it happen...i told the doctor, since my husband was critically sick...actually, there was bleeding in his stomach...this urinary symptom was almost a year...people said that most of the drivers always get this symptom... because they used to hold the urination... actually it was prohibited... when we went to the hospital, we knew that it was prostate (swollen)..."

\section{DISCUSSION}

The long-term care of elderlies contributed to many problems to caregivers. The caregivers who had limited financial resources were forced to endure the high living cost nowadays. Although having limited financial resources, the caregivers could not work because in the meantime, they had to take care the sick elderlies at home. The caregivers who encountered the financial problem usually having the difficulties to make the decision especially pertaining to expenditures. Thus, with the limited financial resources, they needed to plan their daily expenses very well. In addition, taking care of elderlies who have chronic health level have caused the caregivers to save up their money to be used during emergency period. This is because, the sick elderlies are frequently admitted to hospital and high cost of expenses for the treatment purpose ${ }^{13}$.
Moreover, some of the caregivers were old and diagnosed with disease. Nonetheless due to the bustle of caregiving role, they had to neglect their self-health. The caregivers prioritized the elderlies' health more than theirs although they needed to be healthy to perform their caregiving role. The role of caregivers requires good health condition to ease them in giving the care and attention to the sick elderlies. The caregiving roles were not an easy task to be done when the caregivers were also sick. When this situation happens, the caregivers are always in the condition of daily pain and reciprocal suffering ${ }^{14}$.

The changes that happened in the society caused the people to migrate to another places also made it difficult to determine the caregiving rotation. The caregivers who taking care of the elderlies could not rotate with other family members due to the work demands and many more. When the caregiving roles needed to be done for a long period, it could indirectly burden the caregivers. Instead of daily caregiving role, caregivers also had the other roles in their daily life. Therefore, when the caregiving role was only depended on one caregiver, it was feared that it could influence the caregiving quality and affecting the caregiver's well-being. Hence, the caregivers are also needed to be taken care to ensure their walfare is not neglected.

In addition, the lack of information related to disease and caregiving made it hard for caregivers. The researcher found out that the education level also influenced caregiving knowledge level that associated with elderly caregiving matters. The research debunked that most of the informants had low education level which only graduated from standard six. Therefore, they faced difficulties to fathom and search for the information pertaining to health and related matters with elderly caregiving.

Consequently, the role of taking care the sick elderlies was difficult and it was not an easy matter as it required patience and high committment from caregivers. The elderlies who diagnosed with chronic disease needed to depend on other people for a longer period. Besides taking care of sick elderlies, caregivers also had various roles that needed to be executed simultaneously. Plus, there were caregivers who stucked in sandwich family because they needed to take care two generations at the same time. As a result, the impact from caregiving role has caused most of the caregivers to get burdened, isolated and disturbed with the elderlies' caregiving role. The implication is some of the elderlies are being abused and neglected.

\section{CONCLUSION}

The role of taking care the sick and disabled elderlies has burdened the caregivers. Most of the infomal caregivers were actually not capable to 
accommodate the good quality of caregiving service because of lack of financial resources, health problem, limited knowledge and skill related to the sick elderlies caregiving. Although most of the people assumed that long-term caregiving of the elderlies was personal matter, the caregivers also needed the support from many parties including families, government and nongovernment organization. The ability of the caregivers to provide the good quality of caregiving service was restricted because there were a lot of arising problems during the caregiving. However, the long-term caregiving of elderlies did not only touch on the quality aspect, the aspect of caregivers' life happiness also needed to be emphasized. Despite of the caregivers' roles to take care the sick elderlies, the caregivers also need to be taken care of to ensure their well-being is not affected and can provide the good quality of caregiving service towards the elderlies.

\section{ACKNOWLEDGEMENTS}

We acknowledge the support and help Department of Social Welfare Malaysia (JKM). We also indebted to the informal caregivers who had kindly participated in this study.

\section{COMPETING INTEREST}

The authors declare that have no competing interests.

\section{REFERENCES}

1. Rowles GD, Teaster PA. Long -term Care in Aging Society: Theory \& Practice. United States: Springer Publishing Company 2016: 11-14.

2. Nur Syahidah Abdul Jalil.Cabaran peningkatan penduduk lanjut usia. Dlm. Masyarakat Menua: Realiti \& Cabaran, eds. Nur Syahidah Abdul Jalil \& Muhammad Hisyam Mohamad. Kuala Lumpur: Penerbit Institusi Kefahaman Islam Malaysia (IKIM) 2019: 13-27.

3. Jabatan Perangkaan Malaysia. Siaran akhbar anggaran penduduk semasa Malaysia. $2018 \quad-2019$. https://www.dosm.my/pdf. (accessed 20 December 2020).

4. World Health Organisation. Ageing and life course. https: / /www.who.int/ageing/long-termcare/en/ (accessed 20 June 2020).

5. Seow Ta Wee, Sanmargaraja Shalini. Isu Penuaan \& Fasiliti di Rumah Orang Tua. Johor Darul Ta'zim: Penerbit Universiti Tun Hussein Onn Malaysia 2014: 1-4.

6. Yang AL. Long-term care for the elderly in Taiwan. Nursing Science Quarterly 2002; 15 (3): 252-256.

7. Bruhn JG, Rebach HM. The Sociology of Caregiving. New York: Springer 2014: 7-8.

8. Holloway I. A-Z of Qualitative Research in Healthcare. Second Edition. United Kingdom: Blackwell Publishing 2008: 3840.

9. Fatimah Abdullah. Isu dan cabaran penjagaan tidak formal. Malaysian Journal of Social Administration 2009; 6 : 73-86.

10. Khadijah Alavi, Rahim M. Sail, Khairuddin Idris, et al. Pengalaman penjagaan ibu bapa tua oleh anak dewasa: satu kajian dalam kalangan penduduk Melayu bandar berpendapatan rendah. AKADEMIKA 2010; 78 (Jan-April): 77-87.

11. Mohd Suhaimi Mohamad, Fatimah Abdullah, Farid Mat Zin. Gender dan penjagaan tidak formal. Persidangan Antarabangsa Islam, Pembangunan dan Keharmonian Sosial di Asia Tenggara, Princess of Naradhiwas University, Narathiwat, Thailand. 11-12 April 2017.

12. McCullough D. My Mother Your Mother: Embracing "Slow Medicine"- The Campassionate Approach To Caring For Your Aging Loved Ones. New York: Harper Collins Publisher 2009: 71.

13. McGoldrik M, Preto NG, Carter B.The Expanding Family Life Cycle:Individual, Family \& Social Perspectives. $5^{\text {th }}$ edition: United States: Pearson 2016: 345-346.

14. Waldrob DP \& Meeker MA.Crisis in caregiving: when home based end of life care is no longer possible. Journal of Palliative Care 2011; 27 (2): 117-125. 